Bond University ePublications@bond

Sports Law eJournal

Faculty of Law

$8-25-2015$

\title{
Professional sport, work health and safety law and reluctant regulators
}

Eric Windholz

Follow this and additional works at: http://epublications.bond.edu.au/slej

Part of the Law Commons

Recommended Citation

Eric Windholz. (2015) "Professional sport, work health and safety law and reluctant regulators" ,, : ISSN 1836-1129.

http://epublications.bond.edu.au/slej/28

This Journal Article is brought to you by the Faculty of Law at ePublications@bond. It has been accepted for inclusion in Sports Law eJournal by an authorized administrator of ePublications@bond. For more information, please contact Bond University's Repository Coordinator. 


\title{
Professional sport, work health and safety law and reluctant regulators
}

\begin{abstract}
Workplace health and safety (WHS) regulators have been reluctant to investigate professional sports for breaches of WHS law. Using the Essendon Football Club supplements saga as its primary case study, this article explores this reluctance. It concludes that while aspects of the sporting endeavour justify a pragmatic application of WHS laws, professional sport should not be above and beyond WHS laws and regulators. The reasoning behind WHS regulators' decisions not to investigate potential WHS breaches in professional sport should be more transparent.
\end{abstract}

\section{Keywords}

workplace health and safety regulators, workplace health and safety of professional sports people, sport's culture of risk

\section{Disciplines}

Law 


\title{
PROFESSIONAL SPORT, WORKPLACE HEALTH \& SAFETY LAW AND RELUCTANT REGULATORS
}

\author{
ERIC WINDHOLZ*
}

Workplace health and safety (WHS) regulators have been reluctant to investigate professional
sports for breaches of WHS law. Using the Essendon Football Club supplements saga as its
primary case study, this article explores this reluctance. It concludes that while aspects of the
sporting endeavour justify a pragmatic application of WHS laws, professional sport should not
be above and beyond WHS laws and regulators. The reasoning behind WHS regulators'
decisions not to investigate potential WHS breaches in professional sport should be more
transparent.

\section{INTRODUCTION}

The 2013 and 2014 sporting landscape has been dominated by tragedies and scandals that have adversely impacted the health, safety and welfare of professional sportspeople. The spinal injury to Rugby League player Alex McKinnon; the tragic deaths of female jockeys Desiree Gill, Simone Montgomerie, Caitlin Forrest and Carly-Mae Pye and cricketer Phillip Hughes; bullying in the Australian swim team; the ongoing supplements sagas that have plagued the Essendon Football Club and Cronulla Rugby League Club; and hallucinating inducing heat at the Australian Tennis Open, are but a few of the more prominent incidents. These events have given rise to numerous investigations: some by specialist external government agencies; some by the sport's governing body; and some by the clubs involved. Only in a few cases has an investigation been undertaken by a workplace health and safety (WHS) regulator.

This should not come as a surprise. The application of WHS law to professional sport is almost absent from practitioner and academic discourse. ${ }^{1}$ An examination of the websites of Australia's WHS and sport regulators reveals none contains WHS guidance directed to professional sports. ${ }^{2}$

* Monash Centre for Commercial Law and Regulatory Studies, Monash University.

1 Two forms of WHS laws operate in Australia today. Recent efforts to harmonise WHS regimes has produced near identical WHS laws in New South Wales, Queensland, Tasmania, South Australia, Northern Territory, Australian Capital Territory and at the Commonwealth level. Non-harmonised laws continue to operate in Victoria and Western Australia. The two regimes frame and express some WHS duties differently. For example, in harmonised WHS regimes, the primary duty is owed by a person conducting a business or undertaking (PCBU) and is owed to workers; whereas in non-harmonised regimes, the main duty is owed by an employer to an employee (although deeming provisions extend this duty to independent contractors and their employees). Notwithstanding the differences in the way the duties are framed, their nature, content and standards are substantially similar (see Eric Windholz, The harmonisation of Australia's occupational health and safety laws: Much ado about nothing?', (2013) 26 Australian Journal of Labour Law 185). The analysis in this article is by reference to the Work Health and Safety Act 2011 (NSW) (WHS Act) and Work Health and Safety Regulations 2011 (NSW) (WHS Regulations) which are representative of harmonised WHS regimes.

2 Websites reviewed on 3 December 2014 include Commonwealth, State and Territory WHS regulators and institutes of sport, and the Australian Sports Commission.

(a) 2015 the Author. Compilation (C) Centre for Commercial Law. 
Nor is it a matter on which academics have focussed. Leading texts and journals on WHS and sports law contain little, if any, analysis of the application of WHS to professional sport.

Why is this so? Why does the application of WHS law to professional sport lag other commercial endeavours? Why are WHS regulators reluctant to intervene in the affairs of professional sports? Using the Essendon Football Club supplements saga as its primary case study, this article identifies and examines this reluctance.

The Essendon Football Club provides a particularly useful case study. First, the Essendon Football Club and the Australian Football League (AFL) competition within which it competes are representative of other Australian team based professional sporting competitions. ${ }^{3}$ Second, the 'pharmacologically experimental environment' created at the Essendon Football Club, the use of exotic supplements that were never properly documented, the use of external doctors and suppliers outside of established guidelines, the failure in structure and accountability that resulted in the supplements program not being adequately controlled and the frenzied media attention about the legality, efficiency and health effects of the supplements, combine to create a rich factual matrix from which to examine the reluctance of WHS regulators to intervene. ${ }^{4}$ Had these events occurred in the construction, manufacturing or transport industry, for example, it is difficult to imagine WHS regulators not intervening. Yet, WorkSafe Victoria initially was reluctant to investigate choosing to defer to 'more appropriate bodies'. ${ }^{5}$ It only commenced an investigation when compelled by a request from a member of the public. ${ }^{6}$

3 Deborah Healey, 'Governance in sport: Outside the box?' (2012) 23 Economic and Labour Relations Review $39,39$.

4 Space does not permit a forensic analysis of the facts surrounding the development and implementation of the supplements program at the Essendon Football Club; nor is such an analysis necessary. It suffices, for present purposes, to rely on the key findings of the report of Dr Ziggy Switkowski commissioned by the Essendon Football Club (Ziggy Switkowski, Report to the Essendon Football Club (6 May 2013) < http://www.essendonfc.com.au/news/2013-05-06/dr-ziggy-switskowski-report>). In putting this summary forward, however, it should be noted that some of the findings contained in the Switkowski Report remain contested by persons involved.

5 Matt Thompson, 'Supplements saga may drag on for years' (12 July 2013), AFL.com $<$ http://www.afl.com.au/news/2013-07-12/dons-drama-may-drag-on>; Peter Rolfe, 'Top QC Jack Rush to lead Essendon's legal team in fight over supplements scandal', Herald-Sun (online) 8 August 2013 < http://www.heraldsun.com.au/news/victoria/top-qc-jack-rush-to-lead-essendon8217s-legalteam-in-fight-over-supplements-scandal/story-fni0fit3-1226693343496>.

6 Section 131 of the Occupational Health and Safety Act 2014 (Vic) compels WorkSafe Victoria to investigate a matter if requested by a member of the public. WorkSafe Victoria has received three such requests relating to supplement use: one specific to the Essendon Football Club; one in relation to the other Victorian based AFL clubs; and one relating to the AFL. WorkSafe Victoria has advised that it has completed its investigation into the other Victorian based clubs and no further action will be taken. The investigations into the Essendon Football Club and AFL continue (Jon Pierik, 'Nine AFL clubs cleared but WorkCover probe into Essendon, AFL continues', The Age (online) 24 February 2015).

$<$ http://www.theage.com.au/afl/afl-news/nine-afl-clubs-cleared-but-workcover-probe-into-essendonafl-continues-20150223-13mict.html>. 


\section{NARRATIVE 1: SPORT IS NOT WORK; SPORTSPEOPLE ARE NOT WORKERS}

For many, sport is first and foremost a game. It is not work and sportspeople are not workers. As Opie and Smith point out, that one 'plays' sport carries with it the implication that it is something one does when not working. ${ }^{7}$ Hemphill similarly observes that footballers are described as 'players' not 'workers' and the football field is not described as their workplace. ${ }^{8}$ It is, therefore, not surprising that many do not think of professional sport as an activity attracting the protection of WHS laws. A feature of the debate concerning the use of supplements at the Essendon Football Club has been the failure of all, but a few, commentators to view the events as a WHS issue warranting the attention of the relevant WHS regulator. ${ }^{?}$

Popular perceptions aside, however, it is clear that as a matter of WHS law, professional sport is work. Playing, and training and preparing to play, sport professionally satisfies Safe Work Australia's criteria for determining if an activity is work for the purposes of the WHS law. ${ }^{10}$ Professional sport involves physical and mental effort and the application of special skills for which the professional sportsperson is paid. Moreover, the professional sportsperson undertakes their activities as part of a formal and structured competition controlled and directed by others. That professional sport is work covered by WHS laws is reinforced by a detailed examination of the laws themselves. 'Sporting and athletic activities' are excluded from the prevention of falls regulation ${ }^{11}$ and 'plant specifically designed for a sporting activity' is excluded from the plant regulation. ${ }^{12}$ Such exclusions are only necessary if sporting activities are otherwise within the scope of the laws.

7 Hayden Opie and Graham F Smith, 'The Withering of Individualism: Professional Team Sports and Employment Law' (1992) 15 University of New South Wales Law Journal 313, 317.

8 Dennis Hemphill, “ “Think It, Talk It, Work It”: Violence, Injury and Australian Rules Football' (2002) 19(1) Sporting Traditions 17, 18.

9 Outgoing World Anti-Doping Agency President and former NSW Premier John Fahey has been one of the most vocal advocates for WHS regulator involvement, referring to WorkSafe Victoria's initial failure to investigate as 'disgraceful' (Anne Hyland, 'Anti-doping warden not going quietly Fahey away', The Australian Financial Review (online), 14 December 2013

$<\mathrm{http}: / /$ www.afr.com/p/national/arts_saleroom/anti_doping_warden_not_going_to_wwmrQnEiabnv $\mathrm{mC} 3 \mathrm{fSMgYRP}>$. For other commentary critical of WHS regulators' failure to investigate, see: Eric Windholz, 'Time for OHS regulators to get off the bench and into the game', The Conversation, 14 August $2013<$ http://theconversation.com/time-for-ohs-regulators-to-get-off-the-bench-and-into-the-game17039>; Thompson, above n 5; Mathew Dunckley and John Stensholt, 'Essendon set to accept fine, forfeit all season's points', The Australian Financial Review (Sydney), 26 August 2013, 5; Adam Shand, 'AFL chief Andrew Demetriou at risk of legal safety breach', The Australian (online), 4 October 2013 $<$ http://www.theaustralian.com.au/sport/afl/afl-chief-at-risk-of-legal-safety-breach/story-fnca0u4y$1226732566762 \#$ mm-premium>.

10 Safe Work Australia, The Meaning of 'Person Conducting a Business or Undertaking' (Interpretative Guideline Model Work Health and Safety Act, 2011)

<http://www.safeworkaustralia.gov.au/sites/SWA/about/Publications/Documents/606/Interpretive $\% 20$ guideline $\% 20-\% 20$ PCBU.pdf $>$ Safe Work Australia's criteria are consistent with case law on what constitutes 'work'. For a discussion of the case law in this context see SAI Global, Sherriff's Work. Health \& Safety Law Guide, [8.2.1]. Safe Work Australia is a Commonwealth statutory authority with the primary responsibility of improving work health and safety and workers' compensation arrangements across Australia.

11 WHS Regulations, reg 79.

12 WHS Regulations, reg 5. 
The conclusion that professional sport is work enlivens a number of WHS duties. These duties are owed by persons (or entities) whose acts or omissions are capable of affecting the health, safety and welfare of persons at work. These persons (or entities) fall into the following three groups. ${ }^{13}$

First, there are the businesses or undertakings for which the work is done. Persons conducting those businesses or undertakings owe a duty to ensure, so far as is reasonably practicable, the health and safety of workers engaged or caused to be engaged by them, or whose work activities they influence or direct. ${ }^{14}$ The duty on persons conducting a business or undertaking is broad enough to capture sporting clubs that employ players, governing bodies that manage and oversee competitions within which clubs and players participate, and organisers of individual tournaments or events at which players compete as independent contractors (such as tennis tournaments and boxing matches).

Second, officers in effective control of these businesses and undertakings owe a duty to exercise due diligence and to take reasonable steps to ensure the business or undertaking of which they are an officer complies with its WHS duties and obligations. ${ }^{15}$ An important limitation to this duty is that officers who are volunteers do not commit an offence for failing to comply with a health and safety duty. ${ }^{16}$ This is of particular relevance for the directors of sporting clubs and governing bodies, most of whom are not paid for their services. The definition of 'officer' is broader than directors, however. It extends to persons who have significant influence over significant decisions or whose instructions or wishes the directors are accustomed to act on. ${ }^{17}$ This definition captures Chief Executive Officers of clubs, governing bodies and tournament organisers, as well as senior managers responsible for significant areas of their operation. In the case of individual clubs, it also would capture the senior coach, being a person who makes or participates in making decisions that affect, the whole or a substantial part of, the organisation. However, it is less likely that assistant coaches, club doctors and other staff would be caught by the definition, unless it could be established that directors were accustomed to acting in accordance with their instructions.

13 This is the taxonomy employed in SAI Global, above $n$ 10, [8.2.2]. For a fuller analysis of the WHS duties owed by persons involved with team based professional sporting competitions, see Eric Windholz, 'Team-based professional sporting competitions and work, health and safety law: Defining the boundaries of responsibility' (2015) 43 Australian Business Law Review 303.

14 This is the primary duty owed under s 19(1) of the WHS Act. In addition, a person conducting a business or undertaking owes a series of other, more specific duties. These include duties to ensure, so far as is reasonably practicable: the safety of plant, structures and systems of work; the safe use of substances; the provision of adequate welfare facilities; and the provision of adequate information, instruction, training and supervision to enable work to be performed safely and without risks to health (WHS Act, s 19(3)).

15 WHS Act, s 27(1). Reasonable steps required to be taken by an officer include: keeping up-to-date with WHS matters; gaining a general understanding of the WHS risks emanating from the business' or undertaking's operations; ensuring appropriate resources and processes are directed towards eliminating or minimising those risks; and ensuring proper WHS management processes and systems are in place. The officer's duty is conceptually different in non-harmonised regimes. Victoria imposes liability on officers in circumstances where the corporation's breach is attributable to the officer's failure to take reasonable care (Occupational Health and Safety Act 2004 (Vic), s 144), and Western Australia imposes liability on an officer whose consent, connivance or neglect facilitated the corporation's contravention (Occupational Health and Safety Act 2004 (WA), s 55(1)).

16 WHS Act, s 34(1).

17 'Officer' is defined to have the meaning given to the term by section 9 of the Corporations Act (Cth) (WHS Act, s 4). 
Third, workers and other persons who carry out specific activities in support of the sporting endeavour also owe WHS duties. Workers must take reasonable care that their acts or omissions do not adversely affect the health and safety of other persons. ${ }^{18}$ This provision is broad enough to impose WHS duties on players, coaches, doctors, sports scientists and trainers employed or engaged by clubs, and umpires and other officials employed or engaged by governing bodies and tournament organisers. Designers, manufacturers and suppliers of plant and substances used in the sporting endeavour also owe WHS duties to ensure, so far as is reasonably practicable, that the plant or substance is safe and without risks to health. ${ }^{19}$ Plant and substances are defined broadly and include protective equipment used by players, and supplements and like substances taken by, or administered to, players. Finally, venue operators owe a duty to ensure, so far as is reasonably practicable, that the venue at which matches are played is safe and without risks to health. ${ }^{20}$

As can be seen, multiple actors involved with the Essendon Football Club supplements saga owe WHS duties. They include the persons who designed, developed and deployed the supplements program, the persons under whose authority the program was implemented, and the club officials under whose watch it was conducted. The duties also are broad enough to capture the AFL and its officers. That there are multiple duty holders with respect to the same matter does not relieve any one duty holder of their obligations. WHS duties are concurrent, overlapping and non-delegable. Each duty holder must comply with its duties to the extent to which it has control or influence over the matter, even if another duty holder has the same duty. ${ }^{21}$

The duties also are absolute and inchoate. A person's knowledge of the wrongfulness of his/her acts is not an element of an offence, ${ }^{22}$ and exposing persons to risks to their safety or health can give rise to a breach, even if the persons are not subsequently injured or become ill. ${ }^{23}$ Relevantly, 'risk' is defined broadly to include not just actual danger, but also the mere possibility of danger; ${ }^{24}$ and 'risks to health' extends beyond physical health to include psychological health; ${ }^{25}$ and beyond 'freedom from illness or infection' to include 'soundness of body' and the preservation of the general wellness of employees. ${ }^{26}$ Thus, an honestly held belief in the legality of the Essendon Football Club supplements program is not a defense to a breach of duty. Nor, is the fact that to date no-one has become ill as a result of the program. The possibility of illness is sufficient to give rise to a breach, as is the psychological stress and anxiety it may have caused players.

The duties are, however, qualified by the requirement that the duty holder is obliged to do only what is reasonable (reasonably practicable; reasonable steps; reasonable care) in the circumstances. The nature of this qualification is explored in the context of the next narrative.

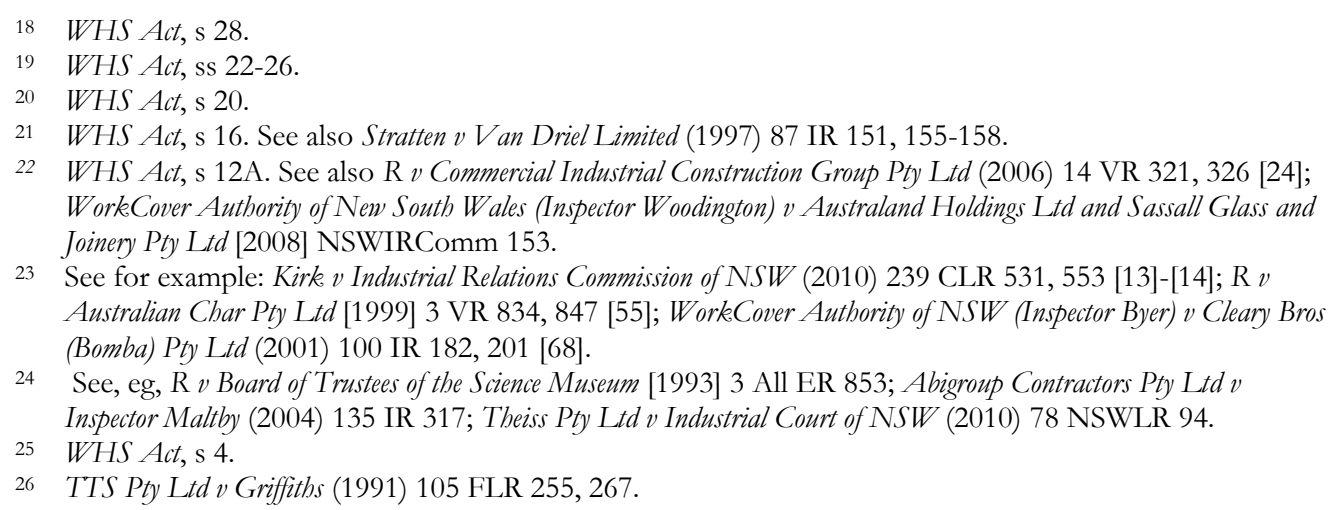




\section{NARRATIVE 2: DIFFERENT RULES APPLY TO SPORTS’ 'CULTURE OF RISK’77}

In several areas of law, sport is treated differently to other industries and activities. The risks and dangers inherent in the sporting contest, and participants' acceptance of those risks, have led courts and legislatures to modify the application to it of traditional legal principles. In negligence cases, for example, courts have allocated to participants 'the majority of the risks of the sporting activity, as part of the trade-off for the preservation of the perceived essential characteristics of sport'. ${ }^{28}$ Further, in criminal cases the general rule that a person cannot consent to the application of force that causes actual bodily harm has been modified by the doctrine of implied sporting consent. ${ }^{29}$ Legislatures similarly have exempted from the scope of workers' compensation legislation, injuries received by persons training or preparing for, or participating in, a sporting or athletic activity. ${ }^{30}$ Legislatures have also crafted exemptions from the application of anti-discrimination legislation, to permit sporting clubs to discriminate on the basis of sex, age and disability. ${ }^{31}$

Professional sport enjoys no such special privileges when it comes to WHS law. No special defences exist, and there is no broad exemption such as exists in workers' compensation legislation. What WHS law requires of persons involved in professional sports is determined by reference to the same legal principles that apply to other industries and work.

Central to these legal principles is the concept of 'reasonableness' (reasonably practicable; reasonable care; reasonable steps). The reasonableness qualifier recognises that WHS law does not require duty holders to ensure accidents never happen. It only requires them to take such steps as are reasonably practicable to ensure the outcome to which the duty is directed which, in the case of persons conducting a business or undertaking, is the health and safety of workers. Courts have emphasised that what is 'reasonably practicable' is to be determined pragmatically (or as 'practical people', to borrow Harper J's description in Holmes $v$ R E Spence \& Co Pty Ltd), ${ }^{32}$ and will vary

27 This is the term used by Hempfill to describe players' acceptance of the risks and dangers inherent in the sporting contest (Hemphill, above $n$ 8, 20).

28 Kylie Burns, 'It's just not cricket: The High Court, sport and legislative facts' (2002) 10 Torts Law Journal 234, 234-235. See also Hayden Opie, 'The sport administrator's charter: Agar v Hyde' (2001) 9 Torts Law Journal 131, 135; Jeremy Kirk and Anton Trichardt, 'Sports, Policy and Liability of Sporting Administrators' (2001) 75 Australian Law Journal 504; Agar v Hyde (2000) 201 CLR 552; Woods v MultiSport Holdings Pty Ltd (2002) 208 CLR 460.

29 For the general rule see $R v$ Brown [1993] 2 All ER 75; R $v$ Stein [2007] VSCA 300. For the doctrine of implied sporting consent see R $v$ Barnes [2005] 2 All ER 113; Bryant v Police [2003] SASC 260.

30 See, eg Workplace Injury Rehabilitation and Compensation Act 2013 (Vic) sch 1, cl 17 that states that injuries incurred by a person engaged by an employer to participate as a contestant in a sporting or athletic activity are not compensable (with the exception of registered jockeys); and Workplace Injury Management and Workers Compensation Act 1998 (NSW) s 4 which excludes a 'registered participant of a sporting organisation' from the definition of 'worker'.

31 See, eg Anti-Discrimination Act 1997 (NSW) ss 38 and 49ZYW which permits the exclusion of persons of one sex or of particular ages from participation in any sporting activity; and Equal Opportunity Act 2010 (Vic) s 72(1) which permits the exclusion 'of people of one sex ... from participating in a competitive sporting activity in which the strength, stamina and physique of competitors is relevant', and s 72(2)(b) permits restricting participation in a sporting activity to people of a specified age or age group.

32 Holmes v R E Spence \& Co Pty Ltd (1993) 5 VIR 119, 123. For a more detailed explanation of 'reasonably practicable' see Safe Work Australia, The Meaning of Reasonably Practicable (Interpretive Guideline - Model Work. Health and Safety Act 2011); Safe Work Australia, How to determine what is reasonably practicable to meet a bealth and safety duty (Safe Work Australia, 2013). 
according to the nature of the activities being undertaken, and the circumstances in which they are undertaken.

The activities undertaken by professional sportspersons can be divided into two broad categories: the sporting contest and other activities. The sporting contest includes the actual competitive contest, and training activities that simulate, to various degrees, the sporting contest. Other activities include exercise, dietary and other conditioning activities engaged in by players to ensure they are in the best physical and mental condition for the sporting contest, and attending public relations, community, charitable and other events at the direction of the club, governing body and/or tournament organiser.

Many sporting contests are inherently risky and dangerous, be it because they are contact or collision sports, or are engaged in with great physicality or speed, or in extreme conditions. Eliminating all risks associated with the sporting contest (actual and simulated), while possible, is unlikely to be reasonable if it involves eliminating from the sport the physicality, excitement and contested essence which attracts participants and spectators, and on which it relies for its popularity and success. However, a sport's inherent risks do not relieve WHS duty holders from their obligations to minimise those risks to the extent reasonably practicable. Indeed, courts have held that the more dangerous the activity being undertaken, the greater should be the level of diligence and vigilance exercised to ensure a safe working environment is provided. ${ }^{33}$ Of course, given many sports' inherent risks, exercising greater diligence and vigilance may not lead to risks being minimised to the extent, or in the manner, that might be expected in relation to other industries and activities.

Determining what is reasonably practicable involves balancing the rough and tumble of the sporting contest with the safety of those who participate in it. This balance is required in the sports' rules and conditions of play, and in the selection of equipment and venues with which, and at which, it is played. Rules that protect the head from unnecessary collision, heat policies that prevent play in extreme conditions, padding on goal posts, and pitch inspections to ensure the safety of the playing surface, are examples of pragmatic and reasonably practicable control measures.

Other activities undertaken by players are different in nature. They do not take place between competitors in the gladiatorial arena. Rather, they take place in more controlled and less risky environments. In the case of the Essendon Football Club supplements program, they took place in medical rooms and offices between club officials in authoritative positions and players, some of whom were young, impressionable and eager to please. ${ }^{34}$ Sports' 'culture of risk' should not be allowed to pervade these activities, or to be used as a justification for providing players engaged in activities away from the sporting field with less protection than is afforded to workers undertaking like activities in other industries.

33 WorkC Cover Authority of New South Wales (Inspector Stothard) v Manildra Park Pty Ltd [2007] NSWIRComm 35 [12]. See also WorkeCover Authority of New South Wales (Inspector Keelty) v Police Service of New South Wales [No 2] (2001) 104 IR 268.

34 Windholz, above $\mathrm{n} 9$. 


\section{NARRATIVE 3: SPORT’S SELF-REgULATORY STATUS}

The large degree of self-regulation afforded to organised sport is another important narrative. A 'mystique', an 'atmosphere of veneration', ${ }^{35}$ an 'air of reverence', ${ }^{36}$ has always attached to sport generally, and professional sport in particular. According to Anderson, this 'mystique' has contributed to minimising sport's exposure to the general law. ${ }^{37}$ At the very least, it helps explain why the law's 'interaction with sport has lagged behind its intersection with other commercial aspects of society'.38

Sport's self-regulatory status is evident in law enforcement agencies' traditional deference to professional sports' internal disciplinary procedures. In all but the most extreme cases, melees (brawls) on the sporting field are dealt with by the sports' disciplinary tribunals, and not the criminal justice system. It also is evident in courts' general reluctance to intervene in the operation of those tribunals. As Lord Denning MR observed in Enderby Town FC v Football Association, justice in a domestic sports tribunal can 'often be done better by a good layman than a bad lawyer'. ${ }^{39}$ The same point also was made, and elaborated upon, by Tadgell JA in Australian Football League v Carlton Football Club Limited, when he said:

courts have been willing to understand that not every aspect of community life is conducted under the auspices of the State, that it is right that this should be so, and that, sometimes, it is appropriate that State-appointed judges stay outside disputes of certain kinds which a private or domestic tribunal have been appointed to decide. The courts have not taken the view that a privately-funded, privately-managed organisation - even one with numerous adherents or devotees and enjoying widespread community popularity - is necessarily to be subject to control by the courts. That is certainly not to say that such an organisation may treat itself as above the law: it is merely to acknowledge that the courts will not discourage private organisations from ordering their own affairs within acceptable limits. ${ }^{40}$

Sport's self-regulatory status also was evident in the role played by the AFL in the Australian Sports Anti-Doping Authority's (ASADA) investigation of the Essendon Football Club supplements saga. As Gowthorp, Greenhow and O’Brien observe, the AFL's strong brand, significant financial resources, superior forensic and investigatory capabilities, and contractual powers to compel players and officials to cooperate with its investigation, combined to make it the dominant actor in the regulatory space with whom ASADA chose to collaborate in the conduct of its investigation. ${ }^{41}$

There are important limitations associated with sports' self-regulating, however, especially in relation to WHS. First, WHS is not the primary focus of clubs, governing bodies and tournament organisers. For clubs, their key performance indicator, and some might say only performance

35 George W Turner (ed), The Australian Pocket Oxford Dictionary (Oxford University Press, 2nd ed, 1984) 451 (definition of 'mystique').

36 Merriam-Webster Online Dictionary and Thesaurus, definition of 'mystique' <http://www.merriamwebster.com/dictionary/mystique>.

37 Jack Anderson, Modern Sports Law (Hart Publishing, 2010) vii.

38 Opie and Smith, above n 7, 315.

39 [1971] Ch 591, 605.

40 (1998) 2 VR 546, 549-550.

41 Lisa Gowthorp, Annette Greenhow and Danny O’Brien, 'An interdisciplinary approach in identifying the legitimate regulator of anti-doping in sport: The case of the Australian Football League', Sport Management Review (forthcoming). See also Peter Harcourt, Francois Marclay and Brett Clothier, 'A forensic perspective of the AFL investigation into peptides: An anti-doping investigation case study' (2014) 48(10) British Journal of Sports Medicine 810. 
indicator, is on-field success. It is somewhat ironic and very telling that the Essendon Football Club's slogan at the time of implementing the supplements program was 'Whatever it takes'. Governing bodies and tournament organisers too have broader priorities. They are concerned with financial returns, satisfying spectators, sponsors and broadcasting partners, and preserving the reputation and integrity of the sporting competition. ${ }^{42}$ Dealing transparently with WHS issues may not always coincide with their broader commercial and reputational interests.

Second, a sport's governing body's self-regulatory jurisdiction is limited. Its investigatory and enforcement powers are limited to persons with whom it has contractual arrangements. In most cases, this is likely to be a narrower set of people than those who owe WHS duties. For example, several persons involved in designing, developing and deploying the supplements programs at the Essendon Football Club may be outside the AFL's contractual reach.

Third, and arguably most importantly, governing bodies and tournament organisers may not be independent and impartial arbiters of WHS matters. As we have seen, they are WHS duty holders with potential liability. The AFL was aware of the dangers performance enhancing drugs and certain supplements posed for the integrity of the competition and the health and safety of the players. The AFL developed an anti-doping code proscribing the use of these substances, conducted training for club officials and players on the code, and established an Integrity Unit to monitor compliance with it. Clearly, the AFL had done a lot in this area. But had it done all that was reasonably practicable? Courts have found franchisors in breach of their WHS duties for failing to ensure warnings given to their franchisees were appropriately acted upon. ${ }^{43}$ The AFL can be likened to a franchisor, licensing players and clubs to participate in its completion according to its rules, policies and procedures. There is evidence that the AFL warned Essendon Football Club Head Coach, James Hird, not to use the supplements subsequently used by the Club, but then failed to monitor the Club to ensure it was following its advice. With respect to this failure, then AFL Chief Executive, Andrew Demetriou, observed that he should have been 'more vigilant' and regretted that the AFL 'didn't do something earlier'. ${ }^{44}$ The AFL Deputy Chief Executive Officer, and now Chief Executive, Gillon McLachlan, similarly commented:

The AFL dropped the ball by not monitoring the Essendon supplement program after advising coach James Hird to steer clear of using peptides in August 2011. ... that we weren't out there regularly monitoring is potentially a failing of the AFL.45

\footnotetext{
42 Healey, above n 3; Domini Stuart, 'The Business of Sports' (1 December 2012) Company Directors Magazine

<http://www.companydirectors.com.au/Director-Resource-Centre/Publications/Company-Directormagazine/2012-back-editions/December/Feature-The-business-of-sports $>$.

43 See, eg, Victorian WorkCover Authority v Yum! (unreported, Broadmeadows Magistrates' Court, Betts M, 18 March 2003, discussed in Michael Tooma, Tooma's Annotated Occupational Health and Safety Act 2004 (Victoria) (Lawbook Co, 2004), [1.23.35]).

44 Shand, above $\mathrm{n} 9$.

45 Ibid.
} 
The AFL has conducted an internal review of its handling of the Essendon Football Club supplements saga, but has not yet released its findings. ${ }^{46}$ The scope of the review, and the extent to which it is a full and critical assessment of the AFL's role, remains to be seen. However, as Harvey and Mathiopoulos observe, the AFL's ambiguous role of simultaneously being policeman, prosecutor, judge and apologist, certainly means it is not an impartial observer. ${ }^{47}$

\section{NARRATIVE 4: OTHER MORE APPROPRIATE INVESTIGATIVE BODIES}

The existence of another more appropriate investigative body was the reason given by both WorkSafe Victoria and WorkCover NSW for their respective decisions not to investigate the use of supplements at the Essendon Football $\mathrm{Club}^{48}$ and Cronulla Rugby League Club. ${ }^{49}$ In both cases they were referring to ASADA. WorkCover NSW was explicit in stating its belief 'that the public interest is served by the actions taken by ASADA in this matter'. ${ }^{50}$

Why ASADA, or indeed any non-WHS regulatory body, is 'more appropriate' is not entirely clear, however. Other regulatory bodies are not responsible for enforcing WHS laws. They do not have WHS as their priority, and do not investigate matters through the prism of WHS. In the case of ASADA, while its legislative mandate is framed in terms of 'sports doping and safety matters', ${ }^{51}$ it expresses its purpose and vision in terms devoid of reference to player health and safety;

Our purpose

To protect Australia's sporting integrity through the elimination of doping.

Our vision

Australia's driving force for pure performance in sport. ${ }^{52}$

ASADA's focus on 'sporting integrity' and 'pure performance in sport' is evident in the manner in which it has investigated supplement use at the Essendon Football Club. It is instructive that 34 of the 37 'show cause' notices issued by ASADA in relation to the matter have been to current or former Essendon Football Club players. This is consistent with the focus of the National AntiDoping Scheme administered by ASADA that places primary responsibility on sportspersons to control what goes into their body. ${ }^{53}$ This is to be contrasted with WHS laws that place primary responsibility on persons in control of businesses or undertakings, to provide their workers with safe working environments and not to expose them to substances that might be injurious to their health.

46 Michael Warner, 'Internal review into the AFL's handling of the Essendon drugs scandal remains a mystery', Herald-Sun (online) 2 March $2015<$ http://www.heraldsun.com.au/sport/afl/internal-reviewinto-the-afls-handling-of-the-essendon-drugs-scandal-remains-a-mystery/story-fni5f22o$1227245256270>$.

47 Matt Harvey and Jim Mathiopoulos, 'The Essendon-ASADA Saga: Player Supplements, Lawyers’ Picnic, Media Feast' (Paper presented at the 2015 Interdisciplinary Colloquium on the Integrity of Sport, Bond University, Gold Coast, Australia, 26-27 February 2015) 2.

48 Thompson, above $\mathrm{n} 5$; Rolfe, above $\mathrm{n} 5$.

49 Email from WorkCover NSW to author, 9 February 2015.

50 Ibid.

51 Australian Sports Anti-Doping Authority Act 2006 (Cth) s 21 (ASADA CEO functions) and s 52 (Australian Sports Drug Medical Advisory Committee functions).

52 ASADA website < http://www.asada.gov.au> accessed 22 February 2015.

53 The National Anti-Doping Scheme is found in sch 1 to the Australian Sports Anti-Doping Authority Regulations 2006 (Cth). 
From a WHS perspective, it is anomalous that the enforcement action is focused primarily on the workers and not on the persons who created the 'pharmacologically experimental environment' within which the supplements were given; ${ }^{4}$ or on the Club officers who failed to put in place adequate governance and management systems to guard against the risk of such an environment being created; 55 or on the AFL's officers who, on their own admission, 'dropped the ball' and should have been 'more vigilant'. ${ }^{56}$ Given the limited focus of ASASDA's investigation, it is difficult to understand how the public interest to which WHS laws are directed - 'protecting workers and other persons against harm to their health, safety and welfare through the elimination or minimisation of risks arising from work or from specified types of substances or plant'57 - is best served by the actions of ASADA.

Moreover, even if ASADA wanted to broaden its investigation, its jurisdictional reach is limited to athletes and support persons, as defined in the Australian Sports Anti-Doping Authority Act 2006 (Cth) and the National Anti-Doping Scheme. This is narrower than the scope of WHS laws, it being unclear, for example, whether all persons involved in designing, developing and supplying the supplements given to the players come within ASADA's jurisdiction. Yet, as former World Anti-Doping Authority President and New South Wales Premier John Fahey observed, some of these people 'are as guilty as or guiltier than the ... athlete. 58

Finally, the existence of other investigations by other bodies is not a good reason for WHS regulators not conducting their own investigations. Parallel investigations of workplace incidents are not uncommon, and most WHS regulators have entered into Memoranda of Understanding with other regulators and law enforcement bodies to facilitate them. Indeed, parallel investigations have been, or are being, conducted by state WHS regulators and Coroners into the deaths of jockeys Simone Montgomerie and Caitlin Forrest, for example. ${ }^{59}$

\section{NARRATIVE 5: WHS REgULATORS’ CAUTIOUS NATURE}

Regulators tend to move cautiously, especially when called upon to enter new fields that are complex or in respect of which their presence is contentious and contested. There are a number of reasons for this caution. Perez, for example, recently wrote of how the three main social systems through which expost judgments of regulatory decisions are made - law (with its focus on outcomes, and less so on intentions and conduct), politics (with its blame and buck-passing culture) and the mass media (with its focus on actors (villains and victims) and avoidance of complexity) - combine to create an environment that encourages passivity, over-cautiousness and defensive tactics on the part of regulators. ${ }^{60}$ Also influential is the 'deregulation' agenda that presently dominates government thinking. All Australian governments have established regulatory reform programs

54 To borrow the term employed by Ziggy Switkowski who was commissioned by the Essendon Football Club to investigate the use of supplements at the Club (Switkowski, above n 4).

55 The breakdown of governance systems was a key finding of the Switkowski Report, ibid.

56 See nn 44 and 45 above.

57 This is the first object listed in the objects clause of the WHS Act, s 3(1)(a).

58 John Fahey, 'Is sport a law unto itself?' (2010) 48(11) Law Society Journal 74, 78.

59 NT WorkSafe, 'Simone Montgomerie Investigation' (Media Release, 23 May 2014); Safe Work SA, 'Confirmation of worker fatality' (Media Statement, 16 October 2014).

60 Oren Perez, 'Courage, regulatory responsibility, and the challenge of higher-order reflexivity' (2013) 8(2) Regulation \& Governance 203, 213-216. 
variably described as 'red tape reduction', 'deregulation' or 'better regulation'. These programs favour 'light' touch regulation and regulators. ${ }^{61}$

WHS regulators are right to be cautious when deciding whether to address WHS issues in a professional sporting context. As we have seen, the application of WHS law to professional sport is complex. Compliance with WHS duties requires difficult judgments to be made and delicate balances to be struck. Nor, is the role of WHS regulators in the field properly understood or recognised, as evidenced by their absence from popular and academic discourse, and the failure of the AFL Players' Association, the union representing AFL footballers, to refer the use of supplements at the Essendon Football Club to the relevant WHS regulator. ${ }^{62}$

However, WHS regulators should not allow this caution to develop into a policy or practice of inaction. How WHS regulators respond to sporting incidents impacts not just the actors involved in the particular incident. It also has the potential to shape people's perceptions about the integrity of WHS laws and the manner with which they are enforced. WHS regulators recently have been criticised for their timid regulation of workplace bullying. ${ }^{63}$ WorkSafe Victoria also was recently criticised by the Hazelwood Mine Fire Inquiry for adopting a narrow reading of its statutory responsibilities, and for the passivity through which it discharged those responsibilities ${ }^{64}$ Criticisms that WHS regulators are not properly discharging their statutory responsibilities go to the heart of public confidence in the regulatory system. WHS regulators need to be careful that their decisions not to investigate WHS breaches in professional sport do not create perceptions that some sectors of the community are too big and some issues too difficult for them to regulate.

\section{NARRATive 6: SPORTINg INCIDENTS ARE Not A REgulatory Priority}

The final narrative considered in this article is that investigating sporting incidents is not a priority for WHS regulators. WHS regulators do not have the resources to investigate all potential breaches of WHS law. Like other government agencies, they are required to prioritise their limited resources among competing demands. The prioritisation process employed by WHS regulators is enshrined in their compliance and enforcement policies. ${ }^{65}$ These policies divide regulatory interventions into two categories: 'targeted' and 'responsive'. Targeted interventions focus on industries, occupations, hazards and/or demographics identified by regulators as part of their strategic planning. Targeted

61 Fiona Haines, The Paradox of Regulation: What Regulation Can Acbieve and What It Cannot (Edward Elgar, 2011) $12-20$.

62 Had these events occurred in another industry, for example the construction, transport or manufacturing industry, it is difficult to imagine the union of the workers involved not referring the matter to the appropriate WHS regulator.

63 See for example House Standing Committee on Education and Employment, Parliament of Australia, Workplace Bullying 'We just want it to stop' (2012) Ch 2 and the submissions received by it which discuss the lack of appropriate regulatory responses to complaints of workplace bullying. See also: Ombudsman Victoria, Investigation into a disclosure about Worksafe's and Victoria Police's handling of a bullying and harassment complaint (April 2007) which describes Worksafe's defensive and risk adverse approach to investigating such complaints.

64 Hazelwood Mine Fire Inquiry, Hazelwood Mine Fire Inquiry Report (Victorian Government Printer, 2004) $18,160$.

65 The analysis in this section is based on the National Compliance and Enforcement Policy developed cooperatively by all WHS regulators and upon which each jurisdiction's compliance and enforcement policy is based (Safe Work Australia, National Compliance and Enforcement Policy (Safe Work Australia, 2011) available at <http://www.safeworkaustralia.gov.au/sites/swa/model-whs-

laws/ncep/pages/ncep>). 
areas generally are either high risk (measured by reference to the volume, severity and/or incidence of workplace injuries), or represent a vulnerable section of the community (eg young workers; migrants). Professional sports are unlikely to be targeted under these criteria.

Responsive interventions, as the name suggests, take place in response to incidents reported by, or complaints received from, duty holders, workers, unions, members of the public or the media. Deciding which incidents or complaints to investigate, and the level of resources to be devoted to that investigation, is fundamentally an exercise of judgement. When making these decisions, the compliance and enforcement policies direct regulators to take the following factors into account: the severity and scale of potential or actual harm; the seriousness of any potential breach of the law; the duty holder's compliance history; its strategic enforcement priorities; the practicality of achieving results; and the wider relevance of the event, including the extent to which the matter is of significant community concern. ${ }^{66}$

These factors are not easy to apply. In any given situation, some factors are likely to weigh against investigating and other factors in favour of investigating. For example, in the case of the Essendon Football Club, the absence of demonstrated harm and the duty holder's compliance history weigh against an investigation. Whereas, the potential harm, the seriousness of the potential breach, and the wider relevance of the event and significant community concern, weigh in favour of an investigation. And while professional sport is not a strategic enforcement priority, young workers are a targeted demographic.

It is clear from this simple example that the decision to investigate or not to investigate a potential breach of WHS law is a matter of judgement about which reasonable minds, and reasonable regulators, can differ. The sporting context only serves to complicate what are already difficult decisions. It is not this author's contention that WHS regulators should investigate all sporting accidents and incidents. It is, however, this author's contention that greater transparency should attach to their decisions and decision making processes. WHS regulators' choices of which incidents to investigate, and which not to investigate, and the process and criteria according to which those choices are made, should be open to critical examination, discussion and debate. A transparent process enhances the legitimacy and credibility of the process by which the decisions are made, and of the decisions themselves. It also facilitates continuous improvement.

Absent such a transparent process, people are left to speculate as to the reasons why some serious sporting incidents are investigated and others are not. For example, why are accidents involving jockeys the only sporting incidents consistently investigated? Is it because of the perception that jockeys are comparatively vulnerable and low paid? Is it the influence and role played by their union, the Australian Workers' Union? Or is it because in most jurisdictions, jockeys are insured under workers' compensation legislation?

Such speculation can give rise to perceptions of special treatment for privileged industries, businesses and/or persons. This, in turn, can undermine regulatory trust and legitimacy. This is particularly dangerous given research establishing that regulatory compliance can depend significantly on people's perception of the legitimacy of the regulatory regime and the regulators within it. ${ }^{67}$

66 Ibid 4-5. Relevantly, an investigation by another investigatory body is not listed as a relevant factor.

${ }_{67}$ See Tom Tyler, Why People Obey the Law: Procedural Justice, legitimacy and Compliance (Princeton University

Press, 1990); Tom Tyler, 'The Psychology of Legitimacy: A Relational Perspective on Voluntary

Deference to Authorities' (1990) 1 Personality and Social Psychology Review 323-345; Valerie Braithwaite,

Kristina Murphy and Monika Reinhart, 'Taxation Threat, Motivational Postures, and Responsive 


\section{CONCLUSION}

This article began by asking why WHS regulators are reluctant to intervene in the affairs of professional sports. A number of narratives explaining this reluctance were identified and examined, and in some cases debunked. Professional sport is work to which WHS laws apply. Different WHS rules do not apply to professional sports, although sports' 'culture of risk' justifies a pragmatic application of those rules to the sporting contest. There are limitations associated with industry self-regulation, and with relying on non-WHS regulators to advance the public interest served by WHS laws. WHS regulators are the most appropriate body to serve the cause of WHS.

WHS regulators are called upon to make complex judgments when deciding which potential breaches of WHS laws to investigate. WHS regulators should exercise caution entering what is for them new, complex and contentious fields. At the same time, however, WHS regulators should not leave themselves open to criticism that they are not properly discharging their statutory responsibilities. Professional sport should not be, nor should it be perceived to be, above WHS law or beyond the reach of WHS regulators. The reasoning behind WHS regulators' decisions to investigate or not to investigate potential WHS breaches in professional sport should be more transparent. This would increase public confidence in both WHS regulators and the decisions they make.

Regulation' (2007) 29 Law and Policy 137; Julia Black, 'Constructing and Contesting Legitimacy and Accountability in Polycentric Regulatory Regimes’ (2008) 2 Regulation \& Governance 137. 